\title{
Kemandirian masyarakat desa wisata dalam perspektif community based tourism: Studi kasus Desa Ketengger, Kabupaten Banyumas
}

\section{Neny Marlina \\ Universitas Diponegoro, Semarang}

\section{KATA KUNCI}

Desa; Desa Wisata; Community

Based Tourism; Komunitas

\section{Pendahuluan}

epariwisataan merupakan salah satu bentuk kebijakan pembangunan nasional yang diarahkan agar mampu mendorong pertumbuhan ekonomi khususnya di tingkat daerah. Pariwisata bukan hanya menjadi sektor yang mampu mengembalikan eksistensi kekayaan lokal baik fisik maupun budaya tetapi juga mampu memperluas kesempatan kerja. Alasan ini

\section{Korespodensi:}

Departemen Politik dan Pemerintahan, Fakultas IImu Sosial dan Ilmu Politik, Universitas Diponegoro, Jl. Prof. Soedarto, Tembalang, Kota Semarang, Jawa Tengah 50139.

Email: nenymarlina@live.undip.ac.id 
diharapkan mampu memberdayakan serta menggerakkan roda ekonomi rakyat. Sektor pariwisata diharapkan dapat menstimulasi kreatifitas serta keterlibatan masyarakat untuk aktif berperan dalam pembangunan serta melestarikan fungsi sekaligus kualitas lingkungan hidup. Menurut Silanne (1994, dalam Wardoyo \& Bahtarudin, 2003) terdapat beberapa faktor yang menjadi dasar pemerintah Indonesia untuk meningkatkan aktivitas pariwisata. Pertama, berkurangnya peranan minyak sebagai penghasil devisa. Kedua, merosotnya nilai ekspor pada sektor non migas serta ketiga, prospek pariwisata yang memperlihatkan kecenderungan meningat. Bahkan, sektor pariwisata merupakan salah satu sektor yang mampu bertahan di tengah gempuran krisis ekonomi pada tahun 1997-998. Peranan pariwisata setidaknya memiliki tiga komponen penting dalam pembangunan, yaitu mencakup segi ekonomi sebagai penyokong perekonomian, segi sosial sebagai alternatif membuka lapangan kerja sekaligus menyerap tenaga kerja setempat, dan segi kebudayaan sebagai wadah bagi eksistensi dan perkembangan budaya lokal yang ada di Indonesia (Wardoyo \& Bahtarudin, 2003).

Pentingnya sektor pariwisata dalam mendukung pembangunan nasional menjadikan pemerintah berada pada posisi sebagai penanggung jawab. Pemerintah harus bertanggung jawab sebagai pembuat serta penegak regulasi. Pada tahun 2018, pariwisata di Indonesia merupakan salah satu dari tiga sektor unggulan pembangunan selain pertanian dan perikanan.

Tabel 1. Indeks Daya Saing Pariwisata Indonesia

\begin{tabular}{|c|c|c|c|c|c|c|c|c|c|c|}
\hline & & & & & 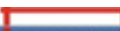 & \multirow{2}{*}{ Philppines } & \multirow{2}{*}{ Vetnam } & \multirow{2}{*}{ LaOFDR } & \multirow{2}{*}{ Camboda } & \multirow{7}{*}{$\begin{array}{l}\text { Menurut } \\
\text { Travel and } \\
\text { Tourism } \\
\text { Competitiv } \\
\text { eness } \\
\text { Report } \\
2017 \text { oleh } \\
\text { World }\end{array}$} \\
\hline Na. & Sublndex/ Pillar & Singupore & Malaysia & Thailund & Indonesia & & & & & \\
\hline \multicolumn{2}{|c|}{ 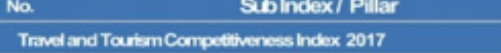 } & 13 & 26 & 34 & 42 & 79 & 67 & 94 & 101 & \\
\hline 1 & BNEUNGEMFONMENT & & & & & & & & & \\
\hline 1 & Bushess Environment & 2 & 17 & 45 & $\infty$ & 82 & 68 & 47 & 125 & \\
\hline 2 & Sabty and Security & 6 & 41 & 118 & 91 & 126 & 57 & 66 & 88 & \\
\hline 3 & Health and Hygiene & 62 & 77 & 90 & 108 & 92 & 82 & 106 & 109 & \\
\hline 4 & Human Resources and Labour Market & 5 & 22 & 40 & 64 & 50 & 37 & 65 & 110 & Economic \\
\hline 5 & CTReadness & 14 & 39 & 58 & 91 & 86 & 80 & 115 & 101 & Forum \\
\hline II & TPME ANDTOUFSMPQCYANDENAUNCOONOMON & & & & & & & & & (WEF), di \\
\hline 6 & Prioritization of Trased and Toursm & 2 & 55 & 34 & 12 & 53 & 101 & 54 & 29 & ASEAŃ, \\
\hline 7 & International Operness & 1 & 35 & 52 & 17 & 60 & 73 & 71 & 58 & Indonesia \\
\hline 8 & Pibe Competiveness & 91 & 3 & 18 & 5 & 22 & 35 & 14 & 51 & 4 setelah \\
\hline 9 & Environmental Sustainability & 51 & 123 & 122 & 131 & 118 & 129 & 98 & 130 & Singapura, \\
\hline III & NFMSIRUCTUE & & & & & & & & & Malaysia, \\
\hline 10 & Air Transport infrastructure & 6 & 21 & 20 & 36 & 65 & 61 & 97 & 96 & dan \\
\hline 11 & Ground and Port Infrastructure & 2 & 34 & 72 & 69 & 107 & 71 & 111 & 108 & Thailand \\
\hline 12 & Tourist Senvice infrastructure & 24 & 46 & 16 & 96 & 87 & 113 & 86 & 102 & \\
\hline N & NATURALANDQUTUFLFESORCS & & & & & & & & & Top Three \\
\hline 13 & Natural Resouros & 103 & 28 & 7 & 14 & 37 & 34 & 71 & 62 & \\
\hline 14 & Cultural Resourcesand Business Traved & 28 & 34 & 37 & 23 & 60 & 30 & 107 & 76 & Bottom \\
\hline & : World Economic Forum (WEF), 2017. & & & & & & & & & Three \\
\hline
\end{tabular}

Berdasarkan Tabel 1 dapat dilihat bahwa daya saing pariwisata di ASEAN, Indonesia menduduki peringkat keempat setelah Singapura, Malaysia, dan Thailand. Namun, pertumbuhan kunjungan mancanegara di Indonesia jumlahnya 3 kali lebih besar dari pertumbuhan regional dan global. Kondisi ini dapat dilihat pada tabel berikut : 
Tabel 2. Pertumbuhan Kunjungan Wisatawan ke Indonesia

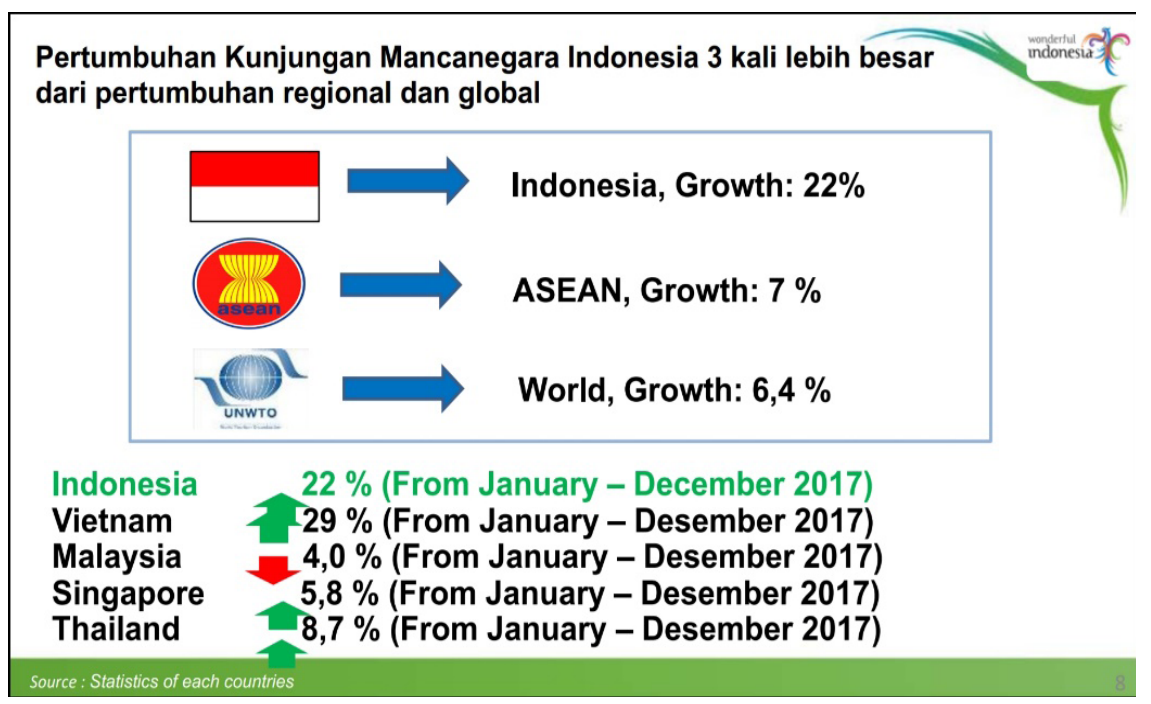

Perkembangan pariwisata tidak cukup hanya mengandalkan bantuan dari pemerintah tetapi membutuhkan peran aktif masyarakat setempat sebagai pelaksana kegiatan pariwisata. Dalam aktivitas pariwisata, masyarakat harus terlibat setidaknya dalam pelaksanaan program pembangunan wisata di daerahnya. Pariwisata baik yang dikelola oleh pemerintah, swasta maupun masyarakat akan memberikan perubahan bagi aktivitas masyarakat lokal yang tinggal di sekitar lokasi wisata. Pengembangan pariwisata dapat memberikan dampak positif dan peluang bagi ekonomi masyarakat. Tumbuhnya sektor jasa di samping pertumbuhan wisata, menjadi peluang penting bagi masyarakat lokal dalam penyerapan tenaga kerja. Sektor ekonomi yang tumbuh dari pariwisata mampu menciptakan peluang bagi lapangan kerja di bidang jasa, seperti hotel, restoran, pejualan souvenir serta transportasi. Selain itu, potensi kekayaan budaya yang mampu dikembangkan jika masyarakat turut serta mulai dari perencanaan kegiatan wisata sampai dengan pertanggungjawaban kegiatan pariwisata.

Pentingnya peran masyarakat sebagai penggerak kegiatan wisata akan melahirkan aktivitas pariwisata yang sesuai dengan potensi lokal yang ada. Hal ini berdampak pada semakin maksimalnya pencapaian tujuan dari aktivitas pariwisata dalam mendorong masyarakat menuju kesejahteraan serta kemandirian. Daerah wisata yang mampu bertahan di tengah perubahan jaman adalah yang mampu berkreasi serta berinovasi dalam pengembangan wisata. Kondisi ini hanya bisa digali jika lahir kesadaran masyarakat serta kepedulian bahwa pariwisata mampu menggerakkan sektor ekonomi rakyat yang berkelanjutan. Artinya, masyarakat setempat maerupakan aktor yang paling memahami kondisi lingkungannya baik dalam melihat kelemahan, kelebihan, tantangan dan peluang.

\section{Mengenali Desa Wisata Ketenger}

Kabupaten Banyumas merupakan salah satu kabupaten yang menjadikan sektor pariwisata sebagai sektor yang berperan penting dalam Pendapatan Asli Daerah (PAD). Kabupaten Banyumas memperoleh juara 1 penghargaan daerah wisata yang paling banyak peminatnya setingkat Jawa 
Neny Marlina $\mid$ Kemandirian masyarakat desa wisata dalam perspektif community based tourism...

Tengah pada tahun 2017 (Satelit Pos, 2018). Kabupaten Banyumas memiliki 6 Desa wisata yaitu desa wisata Tambaknegara, Desa Wisata Plana, Desa Wisata Ketenger, Desa Wisata Kemutug Lor, Desa Wisata Karangsalam dan Desa Wisata Dawuhan. Salah satu Desa Wisata yang paling baik adalah Desa Wisata Ketenger sehingga desa wisata ini dikatakan sebagai desa penyangga bagi Objek Daerah Tujuan Wisata (ODTW) Baturraden. Desa wisata ketenger terletak di Kecamatan Baturaden, Kabupaten Banyumas yang memiliki luas wilayah sebesar 1.120,7 Ha. Desa Ketenger terdiri dari tiga dusun yaitu, Karangpule, Ketenger dan Kalipagu. Desa Ketenger ditetapkan sebagai desa wisata dengan dikeluarkannya Surat Keputusan Bupati Banyumas No. 556/1887/2000 tentang Penetapan Desa Ketenger, Kecamatan Baturraden sebagai Desa Wisata.

Konsep desa wisata berbeda dengan konsep wisata pada umumnya. Desa wisata bukan hanya dituntut memiliki potensi alam yang menarik layaknya wisata alam lainnya melainkan konsep ini lebih mengedepankan karakteristik masyarakat lokal desa dengan segala seluk beluk kondisi alam serta kebudayaannya. Oleh karena itu, sebagai desa wisata tidak cukup hanya berfokus pada pengelolaan ODTW Baturraden tetapi harus mengembangkan budaya serta sejarah yang dimiliki oleh masyarakat lokal. Pengembangan pada sektor lain di luar ODTW Baturaden inilah yang menjadikan Desa Wiata Ketenger menjadi penyangga wisata yang mampu menarik jumlah pengujung lebih banyak lagi. Sejak saat ditetapkannya sebagai desa wisata, desa ketenger mengalami banyak perubahan agar mampu menyangga Kawasan Wisata Baturraden yang menjadi kawasan wisata penting di Banyumas. Desa Wisata Ketenger memiliki daya tarik wisata alam, wisata sejarah dan wisata budaya.

Desa Wisata Ketenger dianugrahi dengan wisata alam yang menarik dan menjadi lokasi tujuan wisata seperti, Curug (air terjun) Gede, Curug Kembar, Curug Bayan, Curug Celiling, Curug Petir, Curug Guman (INews.id, 2018), serta wahana baru yang sudah cukup populer, yaitu Taman Miniatur Dunia atau Small World. Pemandangan alamnya yang hijau membuat Desa Wisata Ketenger menarik minat wisatawan lokal dan mancanegara untuk berlama-lama menikmati keindahan alam yang asri khas pedesaan. Hal ini membuat pengelola desa wisata berinisiatif membuka homestay dan villa sebagai tempat menginap bagi para pengunjung yang ingin merasakan kehidupan alami pedesaan hijau. Sesuai dengan konsep desa wisata, Desa Wisata Ketenger tidak cukup jika hanya berfokus pada pengembangan wisata alam, tetapi juga harus mengembangkan wisata lainnya sebagai wujud konsistensi atas nama yang sudah ditetapkan. Potensi wisata yang dimiliki oleh desa ketenger memang dapat dikatakan cukup banyak diminati oleh masyarakat, belum lagi dengan wisata-wisata yang sedang disiapkan oleh pemerintah desa dan masyarakat untuk menjadi wisata baru di Desa ketenger, seperti Baturlupang sebagai wisata yang telah dikembangkan tahun 2016 yang lalu (Radar Banyumas, 2016).

Desa Ketenger juga memiliki situs peninggalan masa lampau disamping wisata alamnya. Bagi pengunjung yang menyukai pengalaman sejarah yang ada pada suatu daerah, maka dapat mengunjungi wisata sejarah rel Lori. Lori ini pada masanya oleh pemerintahan Belanda digunakan untuk mengangkut hasil hutan seperti tebu dan kopi dari perkebunan menuju pabrik. Wisata sejarah lain juga terdapat waduk Ketenger yang merupakan peninggalan masa pendudukan Jepang, yang sekarang sudah diperbarui dan perbaiki menjadi PLTA dan menjadi lokasi wisata air. 
Wisata budaya juga merupakan wisata yang diminati oleh bayak wisatawan. Salah satu kebudayaan yang disuguhkan kepada pengunjung adalah seni begalan. Begalan adalah kombinasi antara seni tari dan lawak yang diiringi gamelan. Beberapa kesenian yang bisa disajikan untuk menghilangkan dahaga budaya seperti Ebeg (atau kuda lumping/jaran kepang) yaitu atraksi orang dengan menaiki kuda mainan yang terbuat dari ayaman bambu; Siteran yakni sebuah alat musik petik di dalam gamelan Jawa yang dimainkan dengan ibu jari, sedangkan jari lain digunakan untuk menahan getaran ketika senar lain dipetik. Ada juga seni tradisional Begalan yaitu kombinasi antara seni tari dan seni tutur atau seni lawak dengan iringan gending gamelan yang biasanya dipentaskan dalam rangkaian upacara perkawinan; juga terdapat Rengkong, yakni kesenian yang menyajikan bunyi-bunyian khas yang sangat menawan, dilakukan secara serempak yang dihasilkan dari permainan pukulan bambu.

Tujuan wisata yang beragam dan ditawarkan oleh masyarakat desa wisata ketenger ini menunjukkan bahwa atraksi alam bukanlah satu-satunya jenis wisata yang menarik minat wisatawan untuk berkunjung. Wisata yang beragam ini dibuat menjadi paket-paket wisata agar pengunjung dapat menikmati wisata dengan lengkap mulai dari wisata alam, wisata budaya hingga wisata kuliner yang menyajikan makanan khas Kabupaten Banyumas.

\section{Membangun Kemandirian Masyarakat}

Pengelolaan pariwisata di Objek Daerah Tujuan Wisata (ODTW) memerlukan peran serta masyarakat agar dapat mengembangkan pariwisata sekaligus membawa kesejahteraan masyarakat. Pengembangan untuk menjadi desa wisata memerlukan kerjasama dan keikutsertaan seluruh masyarakat desa guna memajukannya. Selain itu dalam pengembangan desa wisata memerlukan perencanaan matang agar dapat menjadi salah satu objek wisata sehingga menjadi kenangan bagi wisatawan (Permanasari, 2010). Pengembangan wisata setidaknya mampu membuka peluang usaha bagi masyarakat sekitar. Oleh karena itu, pelibatan masyarakat dalam pengelolaan pariwisata khususnya di desa sekitar ODTW merupakan instrumen bagi terjadinya pembangunan pariwisata yang terintegrasi. Maka, peran desa wisata di sekitar ODTW Baturraden memegang peran penting sebagai penyangga wisata.

Menurut Timothy (1999) ada dua perspektif dalam melihat partisipasi masyarakat dalam pariwisata. Kedua perspektif tersebut yaitu pertama partisipasi masyarakat lokal dalam proses pengambilan keputusan, dan yang kedua adalah berkaitan dengan manfaat yang diterima masyarakat dari pembangunan pariwisata. Artinya, peran masyarakat baik sebagai sasaran pembangunan pariwisata maupun sebagai aktor pelaksana pembangunan wisata sangat penting dalam siklus pengembangan wisata yang berkelanjutan. Pendekatan pembangunan pariwisata yang tepat melihat perspektif tersebut adalah pendekatan Community Based Tourism (CBT).

CBT merupakan model manajemen pariwisata yang dikelola oleh masyarakat setempat dengan meminimalkan dampak negatif terhadap lingkungan dan budaya dan pada saat yang sama juga menciptakan ekonomi masyarakat yang positif (Ernawati, 2014: 2). Pengelolaan tujuan wisata terutama wisata alam kerap memberikan dampak negatif dari banyaknya pengunjung yang datang. Hal ini sering menimbulkan masalah baru yang menghambat pengembangan pariwisata karena 
Neny Marlina $\mid$ Kemandirian masyarakat desa wisata dalam perspektif community based tourism...

banyaknya pembiayaan yang harus dikeluarkan dalam perawatan maupun perbaikan sarana serta prasarana yang mendukung pariwisata. Keterlibatan masyarakat sekitar sebagai pengawas dalam aktivitas wisata mampu dilibatkan sebagai aktor yang mampu mengurangi dampak negatif tersebut.

Di Desa Ketenger sebagai desa penyangga ODTW Baturraden, penanaman nilai sadar wisata bagi masyarakat merupakan langkah awal setelah ditetapkannya SK Bupati Banyumas mengenai Desa Ketenger sebagai Desa Wisata. Masyarakat dihimpun dalam kelompok sadar wisata atau yang lebih dikenal dengan nama Pokdarwis sebagai kelompok yang diharapkan menjadi motor penggerak kegiatan pariwisata di Desa Wisata Ketenger. Pokdarwis di desa ini terdiri dari 2 kelompok yaitu Pokdarwis Ketenger Adventure yang berdiri pada tahun 2004 dan Pokdarwis Gita Gemilang. Pokdarwis Ketenger baru disahkan dengan Surat Keputusan Kepala Dinas Pemuda, Olahraga, Kebudayaan dan Pariwisata Kabupaen Banyumas No. 556/013.A/I/2011 yang menetapkan tentang pembentukan kelompok sadar wisata sebagai organisasi resmi yang mengelola desa wisata.

Pokdarwis menjadi salah satu konsep dan syarat dalam pengembangan desa wisata dimana keterlibatan masyarakat menjadi sangat penting. Adanya keterlibatan masyarakat menjadi bagian dari Pokdarwis dapat meningkatkan perannya sebagai pelaku pengembangan pariwisata, menumbuhkan dukungan positif masyarakat sebagai tuan rumah serta dapat memperkenalkan, melestarikan dan memanfaatkan potensi daya tarik wisata yang ada didaerahnya.

CBT memiliki beberapa prinsip dalam pengelolaan pariwisata (Suansri, 2003: 12). Pertama, pengelolaan pariwisata membutuhkan keterlibatan anggota ke dalam setiap aktivitas pariwisata. Kedua, baik masyarakat maupun pengunjung wisata mampu secara sadar menjaga kondisi lingkungan hidup yang ada. Ketiga, meskipun pariwisata dikembangkan dengan banyak keterlibatan aktor tetapi pariwisata dengan pendekatan CBT harus tetap menjalankan prinsip kelestarian budaya. Keempat, tujuan pariwisata mengenai kesejahteraan masyarakat akan terwujud jika pengelolaan wisata juga memenuhi prinsip pemerataan pendapatan. Artinya kawasan tujuan wisata tidak hanya mengejar keuntungan ekonomi semata melainkan memperhatikan dampak jangka panjang baik terhadap lingkungan ODTW maupun masyarakat di sekitar kawasan wisata.

Menurut Hudson (dalam Timothy, 1999), ciri-ciri khusus dari CBT adalah diperolehnya manfaat dan adanya upaya perencanaan pendampingan yang membela masyarakat lokal serta kelompok lain memiliki ketertarikan dan minat yang mampu memberikan kontrol lebih besar dalam proses sosial untuk mewujudkan kesejahteraan masyarakat. Artinya, masyarakat yang berada di daerah pengembangan pariwisata harus didorong untuk mengidentifikasi tujuannya sendiri dan mengarahkan pembangunan pariwisata yang bertujuan untuk meningkatkan pemenuhan kebutuhan masyarakat lokal itu sendiri.

Pembangunan pariwisata harus melibatkan masyarakat lokal untuk berpartisipasi, karena hal itu merupakan isu yang mendasar. Partisipasi masyarakat lokal menjadi penting bagi pencapaian desa wisata yang berkelanjutan dan bagi realisasi desa wisata yang baik (Abe, 2002). Kemandirian masyarakat tidak serta merta muncul ketika Desa Ketenger ditetapkan menjadi Desa wisata. Kelompok sadar wisata sebagai penggerak berusaha meningkatkan keterlibatan masyarakat dalam pengembangan wisata. Kondisi ini melahirkan berbagai bentuk upaya pemberdayaan guna 
mendorong partisipasi serta kesadaran masyarakat setempat dalam menggali potensi wisata di Desa Ketenger. Metode yang digunakan dalam upaya memandirikan masyarakat adalah melalui pemberdayaan masyarakat. Pokdarwis bersama masyarakat mengelola paket-paket wisata yang ditawarkan kepada pengunjung seperti paket wisata outbond dan camping. Kegiatan masyarakat ini juga dievaluasi secara rutin setiap satu kali dalam sebulan. Hal ini dilakukan agar meminimalkan kerugian dan dampak negatif dari kegiatan wisata untuk mencapai salah satu tujuan dari CBT yakni keterlibatan aktor dalam kegiatan wisata sekaligus pelestarian lingkungan.

Pokdarwis Ketenger Adventure dalam melakukan kegiatan pemberdayaan kepada masyarakat juga membutuhkan aktor lain agar mampu mencapai tujuan pengembangan wisata yang optimal. Pokdarwis melakukan kerjasama dengan Dinas pemuda, olahraga, kebudayaan dan pariwisata yang menghasilkan dana bantuan PNPM untuk tahun 2010 dan 2013 yang digunakan untuk pembelian peralatan kesenian, pelatihan dan pembangunan sarana prasarana seperti pembangunan dan perlengkapan outbond dan camping (Prafitri \& Damayanti, 2016: 79). Selain itu, pemberdayaan masyarakat juga dilakukan oleh pemerintah terkait dalam mengembangkan keahlian yang mendukung bagi aktivitas pariwisata. Hal ini sejalan dengan pendapat bahwa prinsip dari penyelenggaraan tata kelola kepariwisataan yang baik pada intinya adalah adanya koordinasi dan sinkornasi program antar para pemegang kepentingan dan kekuasaan yang ada serta pelibatan partisipasi aktif yang sinergis (terpadu dan saling menguatkan) antara pihak Pemerintah, swasta/ industri pariwisata, dan masyarakat setempat yang terkait (Sunaryo, 2013: 77).

Pemberdayaan masyarakat diterjemahkan sebagai upaya atau kekuatan yang dilakukan oleh individu ataupun kelompok masyarakat agar masyarakat tersebut dapat berdaya guna dalam memenuhi kehidupannya menuju ke arah kesejahteraan (Mardikanta \& Subianto, 2013). Pemerintah desa bersama dengan Dinas Pariwisata mengadakan pelatihan serta pengarahan tentang homestay yang banyak didirikan sebagai tempat menginap bagi pengunjung. Pelatihan keterampilan bagi masyarakat sekitar untuk menghasilkan produk souvenir yang baik dan menarik wisatawan juga dilakukan dengan peran dari Dinas Koperasi dan UMKM. Produk souvenir yang bisa diperoleh antara lain, kaos, kerajinan logam dan seni lukis dengan media kaca. Pelatihan ini menghasilkan peningkatan kualitas masyarakat dalam menggerakkan roda perekonomiannya dengan memanfaatkan peluang yang ada. Masyarakat yang semula tidak terlibat dalam aktivitas wisata setelah memiliki keterampilan terlibat dalam kegiatan wisata melalui penjualan souvenir. Promosi wisata tidak hanya dilakukan oleh pemerintah tetapi juga oleh pokdarwis bersama masyarakat setempat.

\section{Desa Wisata Ketenger sebagai Penyangga Wisata Baturraden}

Keberhasilan proses untuk mendorong masyarakat Desa Wisata Ketenger menjadi lebih mandiri dengan melibatkannya dalam kegiatan wisata dapat dilihat dari beberapa hal. Pertama, peningkatan kapasitas keahlian masyarakat dalam pengelolaan melalui berbagai pelatihan telah membawa masyarakat menempati posisi yang lebih baik dalam pengelolaan wisata yakni bukan hanya menjadi objek tetapi menjadi subjek yang mendukung berlangsungnya aktivitas wisata. Peningkatan keahlian dan kapasitas masyarakat di beberapa kegiatan juga berdampak pada 
Neny Marlina $\mid$ Kemandirian masyarakat desa wisata dalam perspektif community based tourism...

meningkatkan jumlah homestay dan villa yang dibangun masyarakat. Homestay tahun 2015 hanya ada 14, namun pada tahun 2016 bertambah menjadi 29 homestay (Martiarini, 2017). Hal ini menunjukkan bahwa masyarakat setempat menjadi tuan rumah bagi daerah wisatanya. Kondisi ini sejalan dengan pandangan Sunaryo (2013: 34) bahwa "Kepariwisataan dapat meningkatkan kesejahteraan masyarakat, bukan saja pada aspek kesejahteraan material dan spiritual saja, akan tetapi juga mampu meningkatkan aspek kesejahteraan kultural dan intelektual dari masyarakat sebagai tuan rumah (host) di suatu destinasi wisata".

Kedua, dorongan bagi kemandirian masyarakat menghasilkan jumlah pengunjung yang semakin meningkat sekaligus menarik pihak swasta untuk menjadi investor di Desa Wisata Ketenger. Beberapa wisata yang dikelola masyarakat dengan pihak swasta adalah The Forest, Camping dan The Village. Kegiatan wisata ini memanfaatkan tanah kas desa. Beragamnya potensi yang ada pada sektor wisata membuat Diporabudpar terus berupaya mendorong para pelaku Pokdarwis yang ada di Desa Wisata Ketenger untuk mengembangkan sektor pariwisatanya. Bergabungnya aktor swasta dalam pengelolaan wisata dengan CBT berdampak juga bagi Pemkab yang mendapatkan pajak retribusi sebesar 10 persen dari 15 obyek wisata yang digabungkan dengan milik perorangan. Jumlah pengunjung pun meningkat, yakni pada bulan Januari hingga November 2018 mencapai 2.065.359 orang. Ini artinya melampau dari target awal yang diperkirakan hanya 1.200.000 pengunjung pariwisata yang ada di Kabupaten Banyumas (Satelit Pos, 2018).

Ketiga, pengembangan wisata dengan keterlibatan masyarakat setempat juga memberikan dampak pada Pendapatan Asli Desa (PAD) Desa Wisata Ketenger. PADes Ketenger setelah berdirinya wisata baru Small World mengalami peningkatan yang signifikan. Pada tahun 2016 PADes Ketenger sebesar Rp. 85.918.675,00 sedangkan pada tahun 2017 mengalami kenaikan menjadi sebesar Rp. 310.590.746,00. Hal ini menunjukkan bahwa kemandirian masyarakat yang telah mampu menjalin kerjasama dengan pihak swasta mampu menggerakkan roda perekonomian desa. Bahkan dalam data yang lain dikatakan bahwa untuk memperbaiki jalan kampung masyarakat sudah bisa menggunakan kas desa yang kini mencapai 500 juta per tahun sehingga tidak lagi menunggu bantuan dari pemerintah. Sikap masyarakat yang tidak lagi bergantung pada pemerintah menunjukkan kemandirian yang mulai berjalan. Hal ini tentu saja berdampak baik karena pengelolaan pariwisata tidak lagi hanya bergantung dari bantuan aktor luar tetapi dapat dilakukan dengan lebih banyak melibatkan masyarakat sendiri. Kondisi inilah yang membawa masyarakat Desa Wisata Ketenger menjadi aktor penting dalam menyangga Kawasan wisata Baturraden.

\section{Penutup}

Pengembangan pariwisata yang berkelanjutan memerlukan pendekatan CBT agar mendorong masyarakat untuk menggali serta bertanggung jawab atas aktivitas wisata di wilayahnya. Pendekatan CBT tidak dapat dilepaskan dari konsep pemberdayaan masyarakat yang menjadi suatu rencana dan kegiatan untuk mendorong kemandirian masyarakat dalam pengelolaan pariwisata. Koordinasi dan sinkronisasi peran antar aktor memberikan dampak positif bagi pengembangan Desa Wisata Ketenger. 
Keterlibatan masyarakat dalam aktivitas pariwisata di Desa Wisata Ketenger telah menunjukkan perubahan pada sektor ekonomi masyarakat dan peningkatan PADes. Hal ini menunjukkan berkurangnya ketergantungan masyarakat pada aktor luar dalam mengelola pariwisata. Desa Wisata Ketenger dengan segala potensi wisatanya merupakan salah satu desa penyangga bagi Kawasan Wisata Baturraden. Oleh karena itu, perubahan karakter masyarakat yang mandiri merupakan peran penting dalam menyangga objek daerah tujuan wisata Baturraden.

\section{Ucapan Terima Kasih}

Terima kasih pada rekan-rekan penulis di Departemen Politik dan Pemerintahan karena selalu membuka ruang diskusinya.

\section{Pendanaan}

Penulis tidak menerima bantuan pembiayaan untuk penelitian, kepenulisan (authorship), dan publikasi dari pihak manapun.

\section{Daftar pustaka}

Abe, A. (2002). Perencanaan Daerah Partisipatif. Solo: Pondok Edukasi.

Ernawati, N. M. (2014). Tingkat Kesepian Desa Tihingan-Klungkung, Bali Sebagai Desa Wisata Berbasis Masyarakat. Jurnal Analisis Pariwisata Politeknik Negeri Bali, 10(1).

INews.id. (2018). Menikmati Alam Desa Ketenger Baturraden, Indah Mirip di Luar Negeri. Diakses pada 21 April 2009, dari https://www.inews.id/travel/destinasi/menikmati-alam-desa-ketengerbaturraden-indah-mirip-di-luar-negeri/341762

Mardikanta, T., \& Subianto, P. (2013). Pemberdayaan Masyarakat Dalam Perspektif Kebijakan publik. Bandung: Alfabeta.

Martiarini, R. (2017). Strategi Pengembangan Desa Wisata Melalui Pemberdayaan Masyarakat Desa Ketenger Baturraden. Institut Agama Islam Negeri Purwokerto.

Permanasari, I. (2010). Pengentasan Kemiskinan Melalui Pemberdayaan Masyarakat di Desa Wisata. Jurnal Kepariwisataan Indonesia, 5(1), 57-69.

Prafitri, G. R., \& Damayanti, M. (2016). Kapasitas Kelembagaan dalam Pengembangan Desa Wisata: Studi kasus Desa Wisata Ketenger, Banyumas. Jurnal Pengembangan Kota, 4(1).

Radar Banyumas. (2016). Desa Ketenger Kembangkan Wisata Baru. Diakses pada 21 April 2019, dari https://radarbanyumas.co.id/desa-ketenger-kembangkan-wisata-baru/

Satelit Pos. (2018). Dinporabudpar Penuhi Target Pedapatan. Diakses pada 21 April 2019, dari https://satelitpost.com/regional/purwokerto/dinporabudpar-penuhi-target-pedapatan

Suansri, P. (2003). Community Based Tourism Handbook. Mekong: REST Project.

Sunaryo, B. (2013). Kebijakan Pembangunan Destinasi Pariwisata Konsep dan Aplikasinya di Indonesia. Yogyakarta: Gava Media. 
Neny Marlina | Kemandirian masyarakat desa wisata dalam perspektif community based tourism...

Timothy, D. J. (1999). Participatory Planning a View of Tourism in Indonesia dalam Annals of Research. Anuals of Research, 26(2).

Wardoyo, W. M., \& Bahtarudin. (2003). Kebijakan Pengembangan Kepariwisataan: Studi Kasus Perumusan Kebijakan Desa Wisata Ketenger, Kecamatan Baturraden, Kabupaten Banyumas. Jurnal Pembangunan Pedesaan, 3(1).

\section{Tentang Penulis}

Neny Marlina adalah Dosen Departemen Politik dan Pemerintahan, Fakultas IImu Sosial dan IImu Politik, Universitas Diponegoro. 